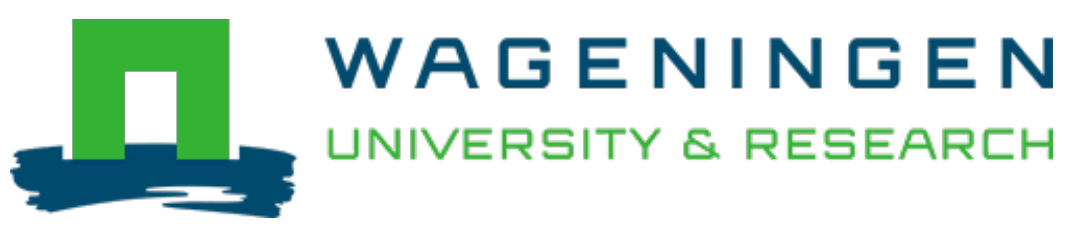

\author{
Prioritising water disinfection technologies to improve food safety of leafy \\ vegetables \\ British Food Journal \\ Asselt, E.D.; Banach, J.L.; Klüche, M.; Appelman, W.A.J. \\ https://doi.org/10.1108/BFJ-03-2020-0197
}

This article is made publicly available in the institutional repository of Wageningen University and Research, under the terms of article $25 \mathrm{fa}$ of the Dutch Copyright Act, also known as the Amendment Taverne. This has been done with explicit consent by the author.

Article 25 fa states that the author of a short scientific work funded either wholly or partially by Dutch public funds is entitled to make that work publicly available for no consideration following a reasonable period of time after the work was first published, provided that clear reference is made to the source of the first publication of the work.

This publication is distributed under The Association of Universities in the Netherlands (VSNU) 'Article $25 \mathrm{fa}$ implementation' project. In this project research outputs of researchers employed by Dutch Universities that comply with the legal requirements of Article $25 \mathrm{fa}$ of the Dutch Copyright Act are distributed online and free of cost or other barriers in institutional repositories. Research outputs are distributed six months after their first online publication in the original published version and with proper attribution to the source of the original publication.

You are permitted to download and use the publication for personal purposes. All rights remain with the author(s) and / or copyright owner(s) of this work. Any use of the publication or parts of it other than authorised under article $25 \mathrm{fa}$ of the Dutch Copyright act is prohibited. Wageningen University \& Research and the author(s) of this publication shall not be held responsible or liable for any damages resulting from your (re)use of this publication.

For questions regarding the public availability of this article please contact openscience.library@,wur.nl 


\title{
Prioritising water disinfection technologies to improve food safety of leafy vegetables
}

\author{
E.D. van Asselt, J.L. Banach and M. Klüche \\ Wageningen Food Safety Research, Wageningen University and Research, \\ Wageningen, The Netherlands, and \\ W.A.J. Appelman \\ Wageningen Food and Biobased Research, Wageningen University and Research, \\ Wageningen, The Netherlands
}

\begin{abstract}
Purpose - Leafy vegetables may get contaminated with pathogens through the use of irrigation water during open field cultivation. The main control option to prevent this contamination is the use of disinfection technologies that will reduce the pathogenic load of the irrigation water. Several technologies, either chemical or physical, are available for disinfection, which were gathered from the literature and European Union (EU) projects. The purpose of this paper is to prioritise these technologies.

Design/methodology/approach - A feasibility study was performed to identify the most promising disinfection technology considering 12 different criteria. A two-tier approach was used in which the technologies were first evaluated based on three criteria: legal status, effectiveness and technology readiness level (TRL). Only the technologies that reached pre-set thresholds for these three criteria were then evaluated in the second tier.

Findings - The evaluation showed that the most promising technologies after the tier-2 evaluation were ultrasound, microfiltration, ultraviolet and ozone. The study showed that the followed approach enabled prioritising disinfection technologies allowing for selecting the most promising technologies that can be tested further on a possible application during primary production to prevent possible food safety issues in leafy vegetables.

Research limitations/implications - The overview is not an exhaustive list of disinfection technologies available rather only those technologies that seemed promising for application in horticulture were addressed. Some technologies may, thus, have been missed. Nevertheless, a total of 12 single and seven combined technologies were evaluated.

Originality/value - This is the first study that uses a structured approach to prioritise a broad range of possible water disinfection technologies for use at primary production.
\end{abstract}

Keywords Feasibility study, Disinfection technologies, Pathogens, Irrigation water, Leafy vegetables,

Microbiological safety, Ranking

Paper type Research paper

\section{Introduction}

Several crops, such as leafy vegetables, are mainly produced in the open field, which makes this produce susceptible to bacterial contamination. Crops may become contaminated with

The experts who participated in this research are kindly thanked for their valuable contribution. The authors gratefully acknowledge Jolanda Medevoort (Wageningen Food and Biobased Research, part of Wageningen University and Research) for contributing to the evaluation of the technology readiness levels. The project partners PB International, Nijhuis Industries, Hessing BV, Heemskerk BV, Palintest Ltd, Sormac BV, Mechanisatiecentrum Flakkee, SmartWashSolutions and Fedecom are kindly thanked for their contribution to this research.

Funding: This work was supported by the Dutch Ministry of Agriculture and Nature and Food Quality (LNV) and was part of the project Safe and Save Water within Topsector Tuinbouw and Uitgangsmaterialen (TU-17003 Safe and save water in de fresh produce supply chain).

Received 19 March 2020 Revised 24 August 2020 1 December 2020 Accepted 3 December 2020 disinfection technologies 
plant pathogens but more importantly with human pathogens. As a result, horticulture products have been implicated with outbreaks of foodborne illnesses in the past. A recent review in the USA showed that between 1973 and 2012, 606 outbreaks were recorded associated with leafy vegetables with 20,003 associated illnesses, 1,030 hospitalisation and 19 reported deaths. Norovirus, Shiga toxin-producing Escherichia coli (STEC) and Salmonella were the most frequent causes of the outbreaks (Herman et al., 2015). Also, in Europe, foods of non-animal origin have been implicated with outbreaks. A prioritisation of the EU outbreaks showed that Salmonella spp. in leafy greens was the most relevant pathogen/food combination in foods of non-animal origin (Da Silva Felício et al., 2015).

Sources of or vectors for microbial contamination of fresh produce in outdoor cultivation include animals, insects, soil, manure, organic fertilisers, equipment, workers and water (FDA, 2015). In particular, the use of irrigation water during leafy vegetable production has been pinpointed as a major source of possible pathogenic contamination (Allende and Monaghan, 2015; Steele and Odumeru, 2004). This concurs with recent pathogenic outbreaks linked to contaminated (irrigation) water such as the 2018 multi-state outbreak with STEC in romaine lettuce, which was most likely caused by contaminated water from an irrigation canal (FDA, 2018).

The extent to which enteric pathogens survive in irrigation water varies substantially depending on the quality and origin of the water (Van der Linden et al., 2014). Irrigation water from different origins might have an impact on the fitness of the transmitting capacity of pathogens, including the ability for pathogens to persist and grow on the surface of lettuce leaves (Van der Linden et al., 2014). Another study, on the irrigation water quality of eight Belgian lettuce producers, confirms that surface water quality is unpredictable; E. coli values for surface water collected from rivers were within the range of 1.5-3.3 $\log$ CFU/mL (Holvoet et al., 2015; Uyttendaele et al., 2015). Competition with resident aquatic microbiota has also shown to influence pathogen behaviour. Persistence and survival on produce were variable, ranging from one day to four weeks on leafy greens (Uyttendaele et al., 2015). In general, the probability of finding pathogens is lowest for potable or rainwater (Lopez-Galvez et al., 2014; Pagadala et al., 2015), intermediate for surface water and recycled or reclaimed water and highest in untreated or inadequately treated water (Pachepsky et al., 2011). A recent survey among European growers showed that groundwater is most often used as an irrigation source. In northwest Europe, $77 \%$ of the respondents used rainwater or groundwater as irrigation water. A minority used surface water $(9 \%)$, tap water $(7 \%)$ and other types such as desalinated water or disinfected urban wastewater $(2 \%)$ (Lechevallier et al., 2018). Given these variations in pathogen survival and water type, strategies should focus on preventing microbial contamination in order to help in decreasing the probability of potential pathogenic contamination in irrigation water (Banach and van der Fels-Klerx, 2020). This is especially important since there are no effective control options further along the supply chain.

In order to prevent possible contamination of fresh produce with pathogens, water can be treated before irrigation. Several disinfection technologies are available for this purpose. These can be either based on chemical treatment, such as the use of chlorine (in the form sodium hypochlorite [ $\mathrm{NaOCl}$ ] or chlorine dioxide, or based on physical treatment, such as ultraviolet-C (UV-C), ultrasound (US) or filtration (Gil et al., 2015). Apart from the application of a single disinfection technology, a combination of disinfection technologies may also be applied. According to a recent review amongst EU vegetable growers, UV is the most commonly applied disinfection technology. It is considered an efficient technology that is safe to use as no chemicals are used (Lechevallier et al., 2018; Dandie et al., 2020). Furthermore, $\mathrm{NaOCl}$ is frequently used for the treatment of irrigation water. Chlorine solutions are frequently used since they are cost-effective, easily available and easy to apply (Dandie et al., 2020; De Corato, 2020). Most disinfection technologies are not effective in inactivating all 
types of pathogens but lead to a reduction in the microbial load. Each of these technologies has its advantages and disadvantages for disinfecting irrigation water. For example, US is very effective in terms of microbial reduction but is seen as costly (Anese et al., 2015), and solar disinfection (SODIS) is seen as a sustainable technology but is currently economically not feasible and weather dependent (Zhang et al., 2018). There are also differences in energy use. Some technologies are more energy-effective (e.g. ozone) than others (e.g. US) (De Corato, 2020; Van Haute et al., 2015). Technologies may also present safety issues. For example, chlorine-based products, like those made of $\mathrm{NaOCl}$, are frequently used as disinfectants. However, this can result in the production of disinfection by-products (DBPs), such as trihalomethane and acetoacetic in the case of chlorine, in the presence of natural organic substances. These DBPs are known to cause chronic human health effects as they are genotoxic and carcinogenic (Collivignarelli et al., 2018). Apart from the adverse effects on human health, DPBs also adversely affect plant physiology, e.g. growth inhibition and lower nutrient concentrations in the plant (Akande et al., 2016). For further information on the water treatment strategies that are used at primary production and their characteristics, we refer to (Banach and van der Fels-Klerx, 2020).

This study aimed to compare available water disinfection technologies and prioritise the most appropriate technologies for disinfecting irrigation water for use in open-field production based on predefined criteria. The focus was on northwest Europe using leafy vegetables as a case study.

\section{Materials and methods \\ Literature study}

The literature was studied to draft a list of possible chemical and physical-based technologies that can be applied to disinfect irrigation water for primary production of leafy vegetables. Possible technologies were included as a search term combined with ("disinfection," "irrigation water" or "wash water") and "horticulture" in Scopus. Furthermore, technologies used in various EU projects (2010-2019) were included in the list. The EU projects studied were PRESERF, VEGITRADE, SUSCLEAN, QUAFETY, DITEC, WHEYSAN, RESFOOD, WHEYCOM, FRESH-DEMO, OX-SHIA, FERTINNOWA and HPGEN. All relevant papers found, i.e. papers dealing with research and development on the technology for purposes of disinfection, were incorporated in an Excel file. The file was set-up with different columns for the authors, the focus of the paper, the disinfection technology used, the product tested, the conditions for testing the disinfection technology, the effectiveness of the technology (pathogenic log reduction), costs (if mentioned) and the technology readiness level (TRL) (NASA, 2012).

\section{Expert elicitation}

Apart from the literature review as described above, experts from private companies, research institutes and branch organisations were asked to provide an input to the list of disinfection technologies included in the study. Once the list of technologies was established, the research team set criteria to qualify these technologies. Experts were asked to add criteria to the list. Then, an online questionnaire was drafted. Experts in horticulture production and/ or disinfection technologies were asked to score the technologies based on certain criteria (see Annex 1). Experts from our network were contacted to participate in this study. The questionnaire was sent to 28 experts by e-mail. The questionnaire was also communicated via social media (Linked-In), to partners of the FERTINNOWA project and during the EU FERTINNOWA project's final conference (3-5 October 2018). In a separate questionnaire, participants were asked to weigh the criteria on their importance to evaluate the feasibility of the disinfection technologies.

\section{Prioritising water disinfection technologies}


The output from the literature study and expert elicitation were combined in an Excel file listing all relevant chemical and physical technologies for water disinfection. The following selection criteria were set in order to prioritise the list of disinfection technologies: legal aspects, effectiveness, TRL, costs, possible side effects, learnability, mobility, the scale of the technology, workers' safety, consumer acceptance, organoleptic effects and robustness of the technology (see Table 1). A two-tier approach was used, allowing for downsizing of the initial list of technologies based on the first three criteria (effectiveness, legal aspects and TRL). Effectiveness was qualified based on the log reduction of pathogenic bacteria achieved, as mentioned in the literature. In the EU, disinfectants are regulated as biocides. Therefore, for evaluating the legal aspects of the disinfectants, the ECHA website was consulted to determine whether biocidal active substances were authorised (https:/echa.europa.eu/). The TRL was classified from 1 to 9 based on the NASA principles (NASA, 2012) with 1: Basic principles observed and reported; 2: Formulation of the technology/concept/application; 3: Experimental proof of concept; 4: Technology validated in lab experiments; 5 : Pilot research; 6: Pilot demonstration; 7: Field or industry-tested; 8: Validation/verification of field or industrial application and 9: Used in practice (the proven concept). The research team evaluated the TRL for each technology based on the available literature and expert opinion. Only those technologies with a TRL $\geq 4$, authorised for use in the EU or currently under review, and with an effectiveness of $\geq 3$-log reduction were further qualified using the additional criteria listed above. The rationale behind these thresholds was that the technologies to be prioritised should be effective and should be available for horticulture growers within the next $3-5$ years.

The technologies that passed the first tier were then evaluated by experts on the remaining criteria in the online questionnaire. A scenario was described, which would help the experts to qualify the various criteria: "We assume growers use surface water for irrigation with high turbidity ( $>10$ NTU). A pre-filtration step will be used to remove suspended solids before the application of the disinfection technology. We assume the technology that is to be used will be automated, e.g. an automated dosing system for applying ozone in the irrigation water" (see Annex 1). For this scenario, the experts were asked to qualify the list of disinfection technologies for the remaining nine criteria, as indicated in Table 1. For costs, additional literature was evaluated to classify the technologies into low $\left(<0.3\right.$ euro $\left./ \mathrm{m}^{3}\right)$, medium $\left(0.3-5\right.$ euro $\left./ \mathrm{m}^{3}\right)$ and high $\left(>5\right.$ euro $/ \mathrm{m}^{3}$ water) costs.

After the results were gathered, all criteria were quantified as 1: best results or 2: worst results. For example, if experts indicated "yes, side-effects are possible", this was quantified as 2 , whereas if experts indicated "no, side-effects are not expected", this was quantified as 1. In case three answers were possible, the answers were quantified into 1, 1.5 and 2. For example, costs were re-scaled from a high, medium and low scale into2, 1.5 and 1, respectively. All scores were added to determine which technology was most feasible (i.e. which had the lowest overall score). Besides equally weighting the criteria, participants were also asked to rank the various criteria from 1: not relevant for evaluating the feasibility of disinfection technologies to 5: very relevant to evaluate the feasibility of disinfection technologies. These weights were used to calculate an adjusted overall score for each of the disinfection technologies.

\section{Results}

Overview of chemical and physical technologies for water disinfection

The literature study and the studied EU projects showed that several technologies are available to disinfect irrigation water (Table 2). Some of these technologies are at an early development stage, while others are already applied in practice to disinfect water. Both single 


\begin{tabular}{|c|c|c|c|c|}
\hline \multirow{2}{*}{$\frac{\text { Criterion }}{\text { Costs }}$} & \multirow{2}{*}{$\begin{array}{l}\text { Explanation } \\
\text { We assume a five-year time period, } \\
\text { taking into account not only the costs of } \\
\text { purchase of the chemicals and machinery } \\
\text { itself but also the energy use required to } \\
\text { run this technology }\end{array}$} & \multicolumn{2}{|c|}{ Possible answers } & \multirow{2}{*}{$\begin{array}{r}\text { Prioritising } \\
\text { water } \\
\text { disinfection } \\
\text { technologies }\end{array}$} \\
\hline & & $\begin{array}{l}(1) \\
(2) \\
(3)\end{array}$ & $\begin{array}{l}\text { High }(>5 \text { euro/m } 3 \text { water }) \\
\text { Medium }(0.3-5 \text { euro/m3) } \\
\text { Low }(<0.3 \text { euro/m } 3)\end{array}$ & \\
\hline \multirow[t]{2}{*}{$\begin{array}{l}\text { Possible side } \\
\text { effects }\end{array}$} & \multirow{2}{*}{$\begin{array}{l}\text { For example, the possible production of } \\
\text { by-products with unknown or adverse } \\
\text { human health effects }\end{array}$} & (1) & $\begin{array}{l}\text { Yes, side effects (e.g. by-products) are } \\
\text { possible }\end{array}$ & \\
\hline & & (2) & $\begin{array}{l}\text { No, there are no known side-effects for } \\
\text { this technology }\end{array}$ & \\
\hline \multirow[t]{2}{*}{ Learnability } & \multirow{2}{*}{$\begin{array}{l}\text { This refers to the easiness for employees } \\
\text { to apply the technology. Is a special } \\
\text { course/training needed to apply the } \\
\text { technology or can it be demonstrated and } \\
\text { applied easily? }\end{array}$} & (1) & $\begin{array}{l}\text { Yes, the technology can be applied with } \\
\text { a simple demonstration }\end{array}$ & \\
\hline & & (2) & $\begin{array}{l}\text { No, the employee requires some } \\
\text { training of the technology }\end{array}$ & \\
\hline \multirow[t]{2}{*}{ Mobility } & \multirow[t]{2}{*}{$\begin{array}{l}\text { Can the technology be easily applied in } \\
\text { the field, e.g. on a moving tractor? }\end{array}$} & (1) & $\begin{array}{l}\text { Yes, the technology can be easily } \\
\text { applied in the field, e.g. on a moving } \\
\text { tractor }\end{array}$ & \\
\hline & & $(2)$ & $\begin{array}{l}\text { No, the technology needs some } \\
\text { adjustments before it can be applied in } \\
\text { the field }\end{array}$ & \\
\hline \multirow[t]{2}{*}{$\begin{array}{l}\text { Scale of } \\
\text { technology }\end{array}$} & \multirow[t]{2}{*}{$\begin{array}{l}\text { This refers to the amount of water that } \\
\text { can be treated with the technology }\end{array}$} & (1) & $\begin{array}{l}\text { Yes, the technology can treat a } \\
\text { considerable amount of water in a short } \\
\text { period of time (i.e. } 80 \mathrm{~m} 3 / \mathrm{h} \text { ) }\end{array}$ & \\
\hline & & $(2)$ & $\begin{array}{l}\text { No, the technology can treat a limited } \\
\text { amount of water and } / \text { or needs a long } \\
\text { period of time (i.e. }<80 \mathrm{~m} 3 / \mathrm{h} \text { ) }\end{array}$ & \\
\hline \multirow[t]{2}{*}{ Workers' safety } & \multirow[t]{2}{*}{$\begin{array}{l}\text { This criterion refers to the effect of the } \\
\text { technology on the workers' safety }\end{array}$} & (1) & $\begin{array}{l}\text { Yes, the technology needs special } \\
\text { requirements in order to protect } \\
\text { workers' safety (e.g. protective } \\
\text { clothing...) }\end{array}$ & \\
\hline & & $(2)$ & $\begin{array}{l}\text { No, the technology can be used without } \\
\text { further requirements }\end{array}$ & \\
\hline \multirow[t]{2}{*}{$\begin{array}{l}\text { Consumer } \\
\text { acceptance }\end{array}$} & \multirow[t]{2}{*}{$\begin{array}{l}\text { This criterion reflects the consumer } \\
\text { perception towards the use of this } \\
\text { technology }\end{array}$} & $\begin{array}{l}(1) \\
(2)\end{array}$ & $\begin{array}{l}\text { The technology will be easily accepted } \\
\text { There might be some reluctance in } \\
\text { accepting this technology }\end{array}$ & \\
\hline & & (3) & $\begin{array}{l}\text { There will be major issues related to the } \\
\text { acceptance of this technology }\end{array}$ & \\
\hline \multirow[t]{2}{*}{$\begin{array}{l}\text { Organoleptic } \\
\text { aspects }\end{array}$} & \multirow[t]{2}{*}{$\begin{array}{l}\text { This criterion refers to the possible } \\
\text { adverse or undesired effect on the } \\
\text { produce in terms of quality }\end{array}$} & (1) & $\begin{array}{l}\text { Yes, the technology may negatively } \\
\text { affect the organoleptic aspects of the } \\
\text { product }\end{array}$ & \\
\hline & & $(2)$ & $\begin{array}{l}\text { No, the technology has no impact on the } \\
\text { organoleptic aspects of the product }\end{array}$ & \\
\hline \multirow[t]{2}{*}{$\begin{array}{l}\text { Robustness of the } \\
\text { technology }\end{array}$} & \multirow[t]{2}{*}{$\begin{array}{l}\text { This criterion refers to the ability of the } \\
\text { technology to obtain the same } \\
\text { effectiveness over time regardless of the } \\
\text { water quality, seasonal or geographic } \\
\text { differences and or technical failures }\end{array}$} & (1) & $\begin{array}{l}\text { Yes, the technology is fail safe } \\
\text { (technical failures will not lead to unsafe } \\
\text { water), and the technology is capable to } \\
\text { deal with fluctuations in water quality } \\
\text { and volume }\end{array}$ & \\
\hline & & $(2)$ & $\begin{array}{l}\text { No, the technology is not fail safe } \\
\text { (technical failures may lead to unsafe } \\
\text { water), or the technology is not capable } \\
\text { to deal with fluctuations in water } \\
\text { quality and volume }\end{array}$ & $\begin{array}{r}\text { Table 1. } \\
\text { Criteria used to } \\
\text { evaluate the various } \\
\text { disinfection } \\
\text { technologies }\end{array}$ \\
\hline
\end{tabular}




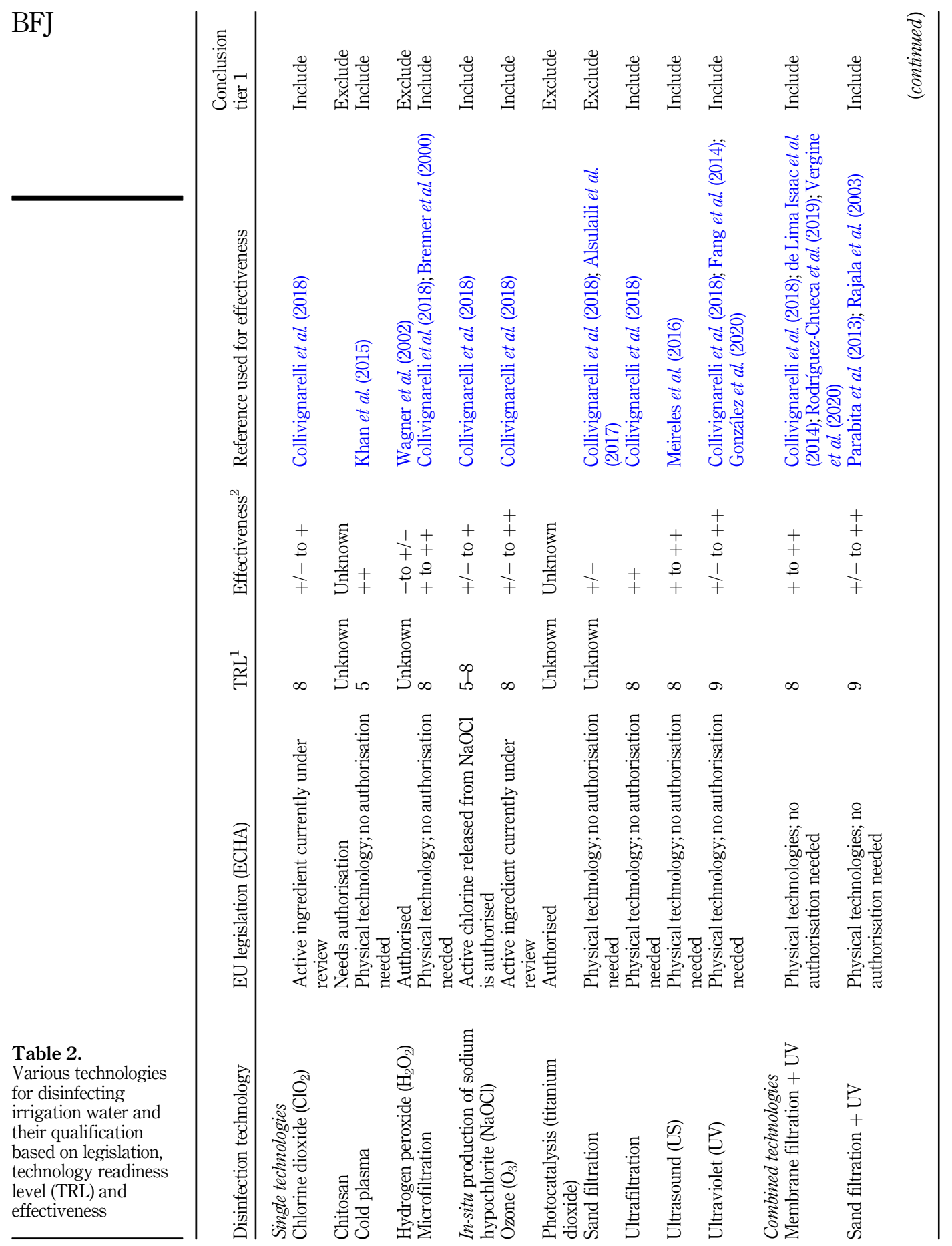




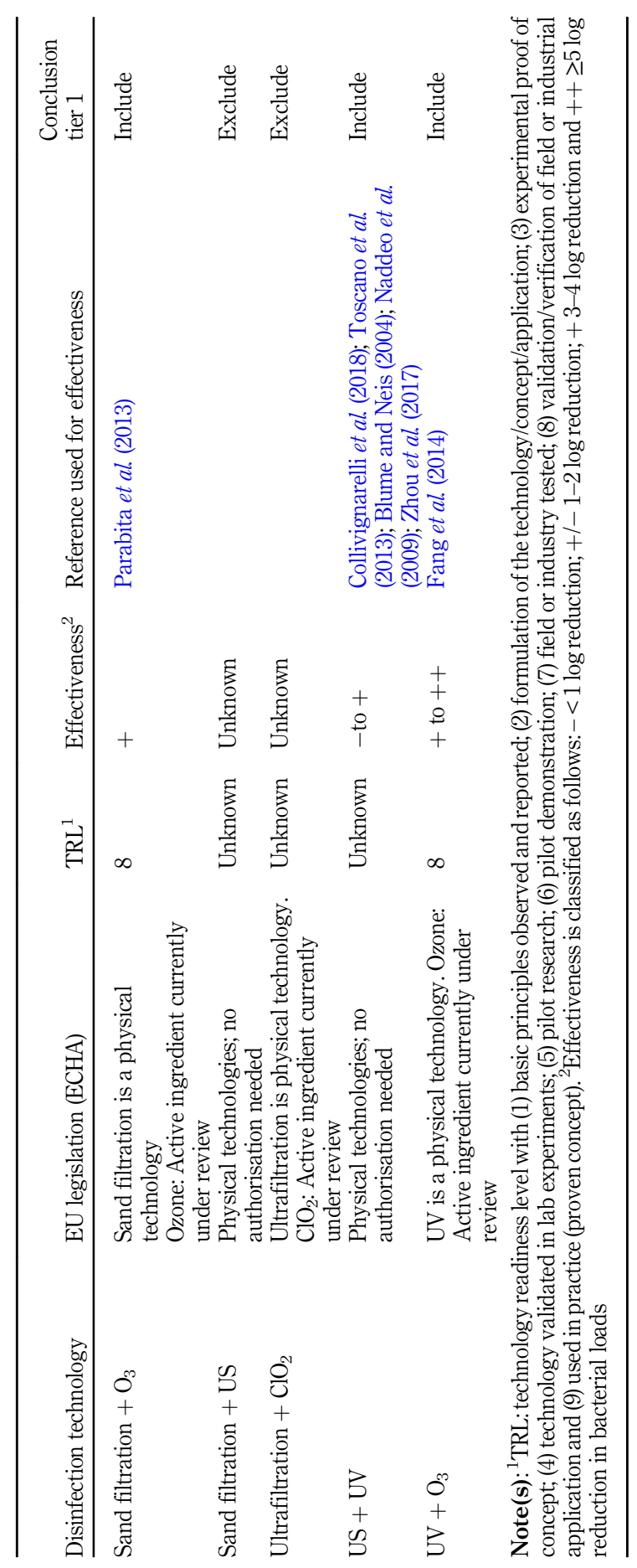

Prioritising disinfection technologies

Table 2. 
and combined technologies were indicated. Studies that mentioned the application of a technology to disinfect the crop itself or the wash water at processing were excluded. Many technologies described were used to disinfect the effluent of wastewater treatment plants. Nevertheless, these technologies could also be used to disinfect surface water used to irrigate crops. Therefore, these technologies were also included in the list. In total, 19 chemical and physical technologies were identified that could potentially be used to disinfect irrigation water.

\section{Prioritisation of technologies}

Tier 1: prioritisation based on legal aspects, effectiveness and TRL. First, the 19 technologies were screened to determine whether they were authorised for use. When technologies were not authorised for use, their effectiveness and TRL were not evaluated, and they were excluded from the further prioritisation of technologies in tier 2 (Table 2). This was the case for the use of chitosan containing products and photocatalysis-based technologies, which are relatively new disinfection technologies for application to irrigation water. When technologies were authorised for use, their effectiveness on reducing bacteria was evaluated. When the technology reached less than a three-log reduction, the TRL was not evaluated, and the technology was not included in the prioritisation performed in tier 2 . This was the case for the use of hydrogen peroxide and sand filtration. All physical technologies were evaluated for their effectiveness, as no authorisation for use is needed. The use of ozone and chlorine dioxide is currently under review for authorisation. It was decided to include these technologies for further prioritisation as well. Table 2 shows that in total, 13 technologies passed the first tier and were prioritised using the nine criteria in tier 2.

Tier 2: final prioritisation. In total, nine experts evaluated the technologies in the online questionnaire. The experts had backgrounds in engineering, quality management, consultancy and research. Not all the experts answered all the questions. Nevertheless, the average score for each criterion was calculated based on all available input, as indicated in the Materials and Method section. The average scores were added to obtain a total score for each disinfection technology (Table 3). Experts were also asked to rank the various criteria showing that the weights of the criteria were comparable, ranging from 3.6 for "learnability" (i.e. the easiness for employees to apply the technology) and "consumer perception towards the technology" to 4.5 on "effect on the produce" (e.g. in terms of organoleptic aspects). The weights were applied to come to a final score for all technologies evaluated (Table 3). Whether or not the criteria were weighted using the weights provided by the experts, the overall outcome was the same. Table 3 shows that the most promising technologies given the presented scenario were US, microfiltration, UV and ozone. These technologies received good scores for the absence of possible side effects, workers' safety, consumer perception and organoleptic aspects. Technologies with the worst overall score for feasibility were cold plasma, in-situ production of $\mathrm{NaOCl}$, a combination of membrane filtration and $\mathrm{UV}$ and chlorine dioxide. Combined technologies ended up in the middle of the list, which is primarily due to scoring poorly on the usability of the technology (learnability, mobility and scale of the technology). Overall, the application of multiple disinfection technologies is more complex than the use of a single technology. Application of multiple technologies requires a finetuning of the technologies applied in order to reach the optimal result, and thus a close collaboration between the technology providers that design the set-up is needed. Furthermore, when multiple technologies are used, the user (in this case, the farmer) needs to get acquainted with these technologies and learn how to act to ensure the systems seamlessly complement one another. This requires more skills and effort from the user. Nevertheless, depending on the quality of the water to be treated, multiple technologies may be necessary to reach a minimally required log reduction. Hurdle technology is increasingly 


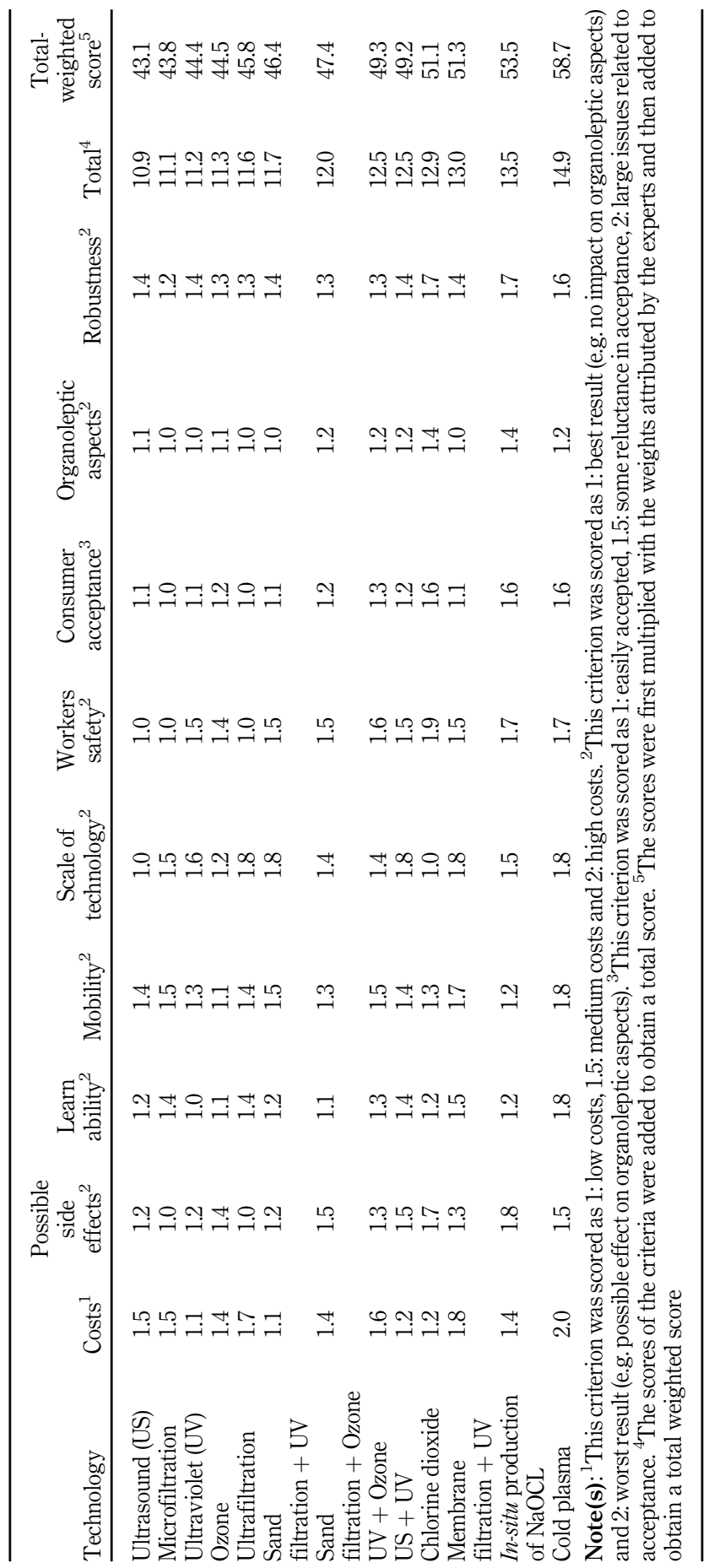

Prioritising water disinfection technologies 
being used as it improves the disinfection efficiency (Deng et al., 2020). Furthermore, the use of multiple technologies allows for maintaining high water quality in case of a failure of one of the individual treatments (Dandie et al., 2020).

\section{Discussion}

The available technologies were prioritised using pre-set criteria. Several methods are available for prioritisation, such as ranking food safety hazards (Van der Fels-Klerx et al., 2018). Since the list of technologies and the selection criteria were comprehensive, a quantitative method was not feasible as this would be too costly and time-consuming. Furthermore, quantitative data on all the criteria were not available. As a result, a more qualified approach was chosen using expert elicitation as the input to the criteria. This may be seen as a weak point in the current evaluation as a different set of experts may evaluate the technologies differently. However, expert elicitation can be useful when trying to evaluate potential problems with a technology or for complex problems, as it can be seen here with the various criteria that can influence the selection of a technology. Despite the limited number of experts participating in this study, they had a broad range of expertise. This contributes to the reproducibility of the study.

In total, 12 criteria (three in tier 1 and nine in tier 2) were identified, and they were used to prioritise the various disinfection technologies. These criteria coincide with those indicated by Van Haute et al. (2015), such as legal status, effectiveness, safety, learnability (complexity of technology) and costs. A two-tier approach was used, which was also suggested by Van Haute et al. (2015), who indicated knockout criteria, i.e. criteria that need to be fulfilled before additional criteria are evaluated. Similar to these authors, both efficiency and legal status were used in our tier 1 . In contrast, the TRL was used as primary selection criteria rather than availability and organoleptic aspects. In our study, we preferred to select those technologies that will be readily available in the next $3-5$ years, and thus technologies with a TRL $\geq 4$. While Van Haute et al. (2015) identified criteria and performed an elaborate evaluation of a limited number of disinfection technologies, our study expands on possible disinfection technologies by prioritising a larger set of disinfection technologies using the literature and expert judgement to qualify the pre-set criteria. This helps to select the most feasible technologies for disinfecting irrigation water in horticulture.

In our study, the various disinfection technologies were ranked using either equal weighting for all criteria or weighted criteria based on expert ranking. The weights for the nine criteria did not greatly differ, which explain why the overall ranking of the technologies was not influenced by the weights of the criteria. However, a study by Van Asseldonk et al. (2018) showed that a grower's willingness to implement a technology is steered by price intervention (discounts and economic incentives). When cost is taken as the only criterion for selection, UV, sand filtration + UV, US + UV and chlorine dioxide were the top four disinfection technologies.

When evaluating all criteria, US, microfiltration, UV and ozone were seen as the top four most feasible disinfection technologies. Although US came out as the most feasible technology, it has a large energy demand (Gibson et al., 2008) and is seen as time and cost consuming when applied at large scale (Anese et al., 2015). The efficiency of physical treatments like US and UV decreases when solids are present (Gil et al., 2009). A pre-filtration step may thus be needed for optimal performance of these technologies. The results of our study concur with the study of Gil et al. (2009) as the robustness for both US and UV were ranked worse, indicating that the treatment is less effective over time. Since other parameters like side effects, learnability, consumer perception and organoleptic effects were ranked high for US and UV, these technologies obtained a high overall ranking. Microfiltration was also in the top four most promising technologies. It is a physical method, thereby resulting in good scores for possible side effects, workers' safety, consumer acceptance and organoleptic 
aspects. Costs are seen as the downside of using microfiltration (van Tongeren et al., 2018). Ozone ended up in the top four most feasible technologies in this study. The possible side effects and workers' safety were seen as less troublesome as compared with chemical disinfectants such as $\mathrm{ClO}_{2}$ and $\mathrm{NaOCl}$. Ozone is an extremely reactive oxidising agent and as such has high efficiency in decreasing bacterial loads (Collivignarelli et al., 2018).

The approach applied in this study helped to prioritise disinfection technologies for irrigation water with a focus on leafy vegetables. While the approach as such may also be used for other horticulture products, the weighting of the criteria might be different for other food crops. It is then recommended to collect data and if needed to perform an expert study specifically for the food crop in question.

\section{Conclusion}

In total, 19 possible disinfection technologies were evaluated on their feasibility to disinfect irrigation water for horticulture using 12 criteria. The top four most optimal technologies were US, microfiltration, UV and ozone. The use of chemical disinfectants, in general, obtained a lower overall ranking due to the possible human health effects, such as the production of DBP. Such effects should be assessed when considering the application of chemical disinfectants. This outcome was based on a pre-set scenario focussing on disinfection of surface water for irrigation of open-field grown leafy vegetables. The results described in this paper can be seen as a first step in identifying the most appropriate technology for disinfecting irrigation water.

Further in-depth studies are needed to evaluate whether these four technologies are indeed suitable for disinfecting irrigation water at large-scale field operations and whether these four technologies are appropriate for different water types. Depending on the source of the water, a pre-filtration step may be needed before applying the disinfection technology. Overall, the use of water disinfection helps to tackle possible food safety issues at the roots of the problem. It is effective to reduce pathogenic loads in irrigation water and thus prevents the introduction of pathogens on the crop before further processing.

\section{References}

Akande, B., Fatoki, O., Odendaal, J., Marnewick, J. and Ndakidemi, P. (2016), "The halogen effects of disinfectant by-products on nutrient concentration, oxidative stress, fatty acids and $\alpha$-tocopherol concentrations in membrane lipids of two Solanum lycopersicum cultivars", Theoretical and Experimental Plant Physiology, Vol. 28 No. 3, pp. 255-271.

Allende, A. and Monaghan, J. (2015), "Irrigation water quality for leafy crops: a perspective of risks and potential solutions", International Journal of Environmental Research and Public Health, Vol. 12 No. 7, pp. 7457-7477.

Alsulaili, A.D., Hamoda, M.F., Al-Jarallah, R. and Alrukaibi, D. (2017), "Treatment and potential reuse of greywater from schools: a pilot study", Water Science and Technology, Vol. 75 Nos 9-10, pp. 2119-2129.

Anese, M., Maifreni, M., Bot, F., Bartolomeoli, I. and Nicoli, M.C. (2015), "Power ultrasound decontamination of wastewater from fresh-cut lettuce washing for potential water recycling", Innovative Food Science and Emerging Technologies, Vol. 32, pp. 121-126.

Banach, J.L. and van der Fels-Klerx, H.J. (2020), "Microbiological reduction strategies of irrigation water for fresh produce", Journal of Food Protection, Vol. 83 No. 6, pp. 1072-1087.

Blume, T. and Neis, U. (2004), "Improved wastewater disinfection by ultrasonic pre-treatment", Ultrasonics Sonochemistry, Vol. 11 No. 5, pp. 333-336.

Brenner, A., Shandalov, S., Messalem, R., Yakirevich, A., Oron, G. and Rebhun, M. (2000), "Wastewater reclamation for agricultural reuse in Israel: trends and experimental results", Water Air and Soil Pollution, Vol. 123 Nos 1-4, pp. 167-182. 
Collivignarelli, M., Abbà, A., Benigna, I., Sorlini, S. and Torretta, V. (2018), "Overview of the main disinfection processes for wastewater and drinking water treatment plants", Sustainability, Vol. 10 No. 1, p. 86.

Da Silva Felício, M.T., Hald, T., Liebana, E., Allende, A., Hugas, M., Nguyen-The, C., Johannessen, G.S., Niskanen, T., Uyttendaele, M. and McLauchlin, J. (2015), "Risk ranking of pathogens in readyto-eat unprocessed foods of non-animal origin (FoNAO) in the EU: initial evaluation using outbreak data (2007-2011)", International Journal of Food Microbiology, Vol. 195, pp. 9-19.

Dandie, C.E., Ogunniyi, A.D., Ferro, S., Hall, B., Drigo, B., Chow, C.W.K., Venter, H., Myers, B., Deo, P., Donner, E. and Lombi, E. (2020), "Disinfection options for irrigation water: reducing the risk of fresh produce contamination with human pathogens", Critical Reviews in Environmental Science and Technology, Vol. 50 No. 20, pp. 2144-2174.

De Corato, U. (2020), "Improving the shelf-life and quality of fresh and minimally-processed fruits and vegetables for a modern food industry: a comprehensive critical review from the traditional technologies into the most promising advancements", Critical Reviews in Food Science and Nutrition, Vol. 60 No. 6, pp. 940-975.

de Lima Isaac, R., dos Santos, L.U., Tosetto, M.S., Franco, R.M.B. and Guimarães, J.R. (2014), "Urban water reuse: microbial pathogens control by direct filtration and ultraviolet disinfection", Journal of Water and Health, Vol. 12 No. 3, pp. 465-473.

Deng, L.Z., Mujumdar, A.S., Pan, Z., Vidyarthi, S.K., Xu, J., Zielinska, M. and Xiao, H.W. (2020), "Emerging chemical and physical disinfection technologies of fruits and vegetables: a comprehensive review", Critical Reviews in Food Science and Nutrition, Vol. 60 No. 15, pp. 2481-2508.

Fang, J.Y., Liu, H.L., Shang, C.I., Zeng, M.Z., Ni, M.L. and Liu, W. (2014), "E. coli and bacteriophage MS2 disinfection by UV, ozone and the combined UV and ozone processes", Frontiers of Environmental Science and Engineering, Vol. 8 No. 4, pp. 547-552.

FDA (2015), "Analysis and evaluation of preventive control measures for the control and reduction/ elimination of microbial hazards on fresh and fresh-cut produce: chapter IV. Outbreaks associated with fresh and fresh-cut produce. Incidence, growth, and survival of pathogens in fresh and fresh-cut produce", available at: http://www.fda.gov/Food/FoodScienceResearch/ SafePracticesforFoodProcesses/ucm091265.htm (accessed 18 April 2016).

FDA (2018), "Environmental assessment of factors potentially contributing to the contamination of romaine lettuce implicated in a multi-state outbreak of E. coli O157:H7", available at: https:// www.fda.gov/Food/RecallsOutbreaksEmergencies/Outbreaks/ucm624546.htm.

Gibson, J.H., Yong, D.H.N., Farnood, R.R. and Seto, P. (2008), "A literature review of ultrasound technology and its application in wastewater disinfection”, Water Quality Research Journal of Canada, Vol. 43 No. 1, pp. 23-35.

Gil, M.I., Selma, M.V., Lopez-Galvez, F. and Allende, A. (2009), "Fresh-cut product sanitation and wash water disinfection: problems and solutions", International Journal of Food Microbiology, Vol. 134 Nos 1-2, pp. 37-45.

Gil, M.I., Selma, M.V., Suslow, T., Jacxsens, L., Uyttendaele, M. and Allende, A. (2015), "Pre- and postharvest preventive measures and intervention strategies to control microbial food safety hazards of fresh leafy vegetables", Critical Review in Food Science and Nutrition, Vol. 55 No. 4, pp. $453-468$.

González, Y., Salgado, P. and Vidal, G. (2020), "Disinfection behavior of a UV-treated wastewater system using constructed wetlands and the rate of reactivation of pathogenic microorganisms", Water Science and Technology, Vol. 80 No. 10, pp. 1870-1879.

Herman, K.M., Hall, A.J. and Gould, L.H. (2015), "Outbreaks attributed to fresh leafy vegetables, USA, 1973-2012”, Epidemiology and Infection, Vol. 143 No. 14, pp. 3011-3021.

Holvoet, K., Sampers, I., Seynnaeve, M., Jacxsens, L. and Uyttendaele, M. (2015), “Agricultural and management practices and bacterial contamination in greenhouse versus open field lettuce production", International Journal of Environmental Research and Public Health, Vol. 12 No. 1, pp. 32-63. 
Khan, M.S.I., Lee, E.J. and Kim, Y.J. (2015), "Roles of individual radicals generated by a submerged dielectric barrier discharge plasma reactor during Escherichia coli O157:H7 inactivation”, Aip Advances, Vol. 5 No. 10, pp. 107111-1 - 107111-9.

Lechevallier, E., Stavridou, E., Granell-Ruiz, R., Key, G. and Berckmoes, E. (2018), "FERTINNOWA benchmark report - deliverable 3.3", CATE, p. 118.

Lopez-Galvez, F., Allende, A., Pedrero-Salcedo, F., Alarcon, J.J. and Gil, M.I. (2014), "Safety assessment of greenhouse hydroponic tomatoes irrigated with reclaimed and surface water", International Journal of Food Microbiology, Vol. 191, pp. 97-102.

Meireles, A., Giaouris, E. and Simões, M. (2016), "Alternative disinfection methods to chlorine for use in the fresh-cut industry", Food Research International, Vol. 82, pp. 71-85.

Naddeo, V., Landi, M., Belgiorno, V. and Napoli, R.M.A. (2009), "Wastewater disinfection by combination of ultrasound and ultraviolet irradiation”, Journal of Hazardous Materials, Vol. 168 No. 2, pp. 925-929.

NASA (2012), "Technology readiness level”, available at: https://www.nasa.gov/directorates/heo/scan/ engineering/technology/txt_accordion1.html.

Pachepsky, Y., Shelton, D.R., McLain, J.E.T., Patel, J. and Mandrell, R.E. (2011), "Chapter two - irrigation waters as a source of pathogenic microorganisms in produce: a review", in Sparks, D.L. (Ed.), Adv. Agron., Academic Press, pp. 75-141.

Pagadala, S., Marine, S.C., Micallef, S.A., Wang, F., Pahl, D.M., Melendez, M.V., Kline, W.L., Oni, R.A., Walsh, C.S., Everts, K.L. and Buchanan, R.L. (2015), "Assessment of region, farming system, irrigation source and sampling time as food safety risk factors for tomatoes", International Journal of Food Microbiology, Vol. 196, pp. 98-108.

Parabita, C., Guglielmi, L., Canovi, L., Sorlini, S., Gialdini, F., Furatian, L. and Santoro, D. (2013), "Experimental assessment of RSF, UF, RSF-O3 and RSF-H2O2/UV for unrestricted agricultural wastewater reuse in Italy", Water Practice and Technology, Vol. 8 No. 1, pp. 70-82.

Rajala, R.L., Pulkkanen, M., Pessi, M. and Heinonen-Tanski, H. (2003), "Removal of microbes from municipal wastewater effluent by rapid sand filtration and subsequent UV irradiation", Water Science and Technology, Vol. 47 No. 3, pp. 157-162.

Rodríguez-Chueca, J., Mesones, S. and Marugán, J. (2019), "Hybrid UV-C/microfiltration process in membrane photoreactor for wastewater disinfection", Environmental Science and Pollution Research, Vol. 26 No. 36, pp. 36080-36087.

Steele, M. and Odumeru, J. (2004), "Irrigation water as source of foodborne pathogens on fruit and vegetables", Journal of Food Protection, Vol. 67 No. 12, pp. 2839-2849.

Toscano, A., Hellio, C., Marzo, A., Milani, M., Lebret, K., Cirelli, G.L. and Langergraber, G. (2013), "Removal efficiency of a constructed wetland combined with ultrasound and UV devices for wastewater reuse in agriculture”, Environmental Technology, Vol. 34 No. 15, pp. 2327-2336.

Uyttendaele, M., Jaykus, L.-A., Amoah, P., Chiodini, A., Cunliffe, D., Jacxsens, L., Holvoet, K., Korsten, L., Lau, M., McClure, P., Medema, G., Sampers, I. and Rao Jasti, P. (2015), "Microbial hazards in irrigation water: standards, norms, and testing to manage use of water in fresh produce primary production", Comprehensive Reviews in Food Science and Food Safety, Vol. 14 No. 4, pp. 336-356.

Van Asseldonk, M.A.P.M., Malaguti, L., Breukers, M.L.H. and van der Fels-Klerx, H.J. (2018), "Understanding preferences for interventions to reduce microbiological contamination in Dutch vegetable production", Journal of Food Protection, Vol. 81 No. 6, pp. 892-897.

Van der Fels-Klerx, H.J., Van Asselt, E.D., Raley, M., Poulsen, M., Korsgaard, H., Bredsdorff, L., Nauta, M., D'Agostino, M., Coles, D., Marvin, H.J.P. and Frewer, L.J. (2018), "Critical review of methods for risk ranking of food-related hazards, based on risks for human health", Critical Reviews in Food Science and Nutrition, Vol. 58 No. 2, pp. 178-193.

\section{Prioritising water disinfection technologies}


Van der Linden, I., Cottyn, B., Uyttendaele, M., Berkvens, N., Vlaemynck, G., Heyndrickx, M. and Maes, M. (2014), "Enteric pathogen survival varies substantially in irrigation water from Belgian lettuce producers", International Journal of Environmental Research and Public Health, Vol. 11 No. 10, pp. 10105-10124.

Van Haute, S., Sampers, I., Jacxsens, L. and Uyttendaele, M. (2015), "Selection criteria for water disinfection techniques in agricultural practices", Critical Reviews in Food Science and Nutrition, Vol. 55 No. 11, pp. 1529-1551.

van Tongeren, W., Appelman, W., Berckmoes, E., van Calenberge, B., Blind, M., Bolivar Paypay, V., Mariakakis, I., Gimenez, M., Campillo, C. and Carrasco, J. (2018), "Inventory of innovative technologies of other sectors", FERTINNOWA Deliverable 4.2, p. 172.

Vergine, P., Amalfitano, S., Salerno, C., Berardi, G. and Pollice, A. (2020), "Reuse of ultrafiltered effluents for crop irrigation: on-site flow cytometry unveiled microbial removal patterns across a full-scale tertiary treatment", Science of the Total Environment, Vol. 718, pp. 137298-1 -137298-9.

Wagner, M., Brumelis, D. and Gehr, R. (2002), "Disinfection of wastewater by hydrogen peroxide or peracetic acid: development of procedures for measurement of residual disinfectant and application to a physicochemically treated municipal effluent", Water Environment Research, Vol. 74 No. 1, pp. 33-50.

Zhang, Y., Sivakumar, M., Yang, S., Enever, K. and Ramezanianpour, M. (2018), “Application of solar energy in water treatment processes: a review”, Desalination, Vol. 428, pp. 116-145.

Zhou, X., Yan, Y., Li, Z. and Yin, J. (2017), "Disinfection effect of a continuous-flow ultrasound/ ultraviolet baffled reactor at a pilot scale”, Ultrasonics Sonochemistry, Vol. 37, pp. 114-149.

\section{Appendix}

The appendix file is available online for this article.

\section{Corresponding author}

E.D. van Asselt can be contacted at: esther.vanasselt@wur.nl

For instructions on how to order reprints of this article, please visit our website:

www.emeraldgrouppublishing.com/licensing/reprints.htm

Or contact us for further details: permissions@emeraldinsight.com 